\title{
Storage media for avulsed teeth: review of literature
}

\author{
Maristela Gutiérrez de Borba ${ }^{\mathrm{a}}$, Ana Helena G de Alencar ${ }^{\mathrm{b}}$, José Antônio Poli de Figueiredo ${ }^{\mathrm{a}}$, Carlos Estrela ${ }^{\mathrm{b}}$
}

\begin{abstract}
Tooth avulsion is a traumatic injury which can cause severe consequences to permanent dentition, because of the possible damage to periodontal structure. Immediate replantation is the best procedure. However, it sometimes cannot be performed and the success depends on the duration of extra-alveolar time and storage medium of the tooth. The objective of this paper is to review the literature about storage media due to its importance to replantation prognosis. Although innumerous storage media have been tested until now, none of them has the biological requirements and is available at the local accident. Saliva and water are easily accessible, although causing deleterious effects on periodontal cells. Growth factors have biological effects, though they are inaccessible. Thus, its use is impracticable. Propolis and green tea extract seem to be promising and new researches should be carried out. Milk, specially skimmed long shelf-life, seems to be a good option due to its cell viability good results besides its accessibility.
\end{abstract}

Key words: Tooth avulsion; milk; propolis; camellia sinensis; saliva

\section{Meios de conservação do dente avulsionado: revisão da literatura}

\section{Resumo}

A avulsão é um traumatismo dentário de graves consequências para o dente permanente pelo dano que pode ocorrer à estrutura periodontal. O reimplante imediato deve ser o tratamento de eleição, porém muitas vezes não é possível, e o sucesso do futuro reimplante dependerá do tempo em que o dente permanece fora do alvéolo e o meio no qual ele é mantido. O objetivo deste trabalho é fazer uma revisão da literatura sobre os meios de conservação devido a sua importância no prognóstico do reimplante. Embora muitos meios venham sendo testados, até o momento nenhum deles preenche todos os requisitos biológicos e ainda esteja disponível no local do acidente. A saliva e a água, embora sejam de fácil acesso, têm demonstrado causar efeitos deletérios nas células do ligamento periodontal. Apesar dos seus efeitos biológicos positivos, os meios de cultura raramente estão ascessíveis no local do acidente, o que torna seu uso impraticável. A própolis e o extrato de chá verde parecem ser promissores e novos estudos ainda precisam ser realizados. O leite, em especial o longa vida desnatado, parece ser uma boa opção, pois apresenta bons resultados com relação à viabilidade celular e costuma estar disponível.

Palavras-chave: Avulsão dentária, leite, própolis, chá verde, saliva
Clinical Department - Dental School, Pontifical Catholic University of Rio Grande do Sul, Rio Grande do Sul, Brazil

Department of Endodontics, Federal University of Goiás, Goiânia, GO, Brazil

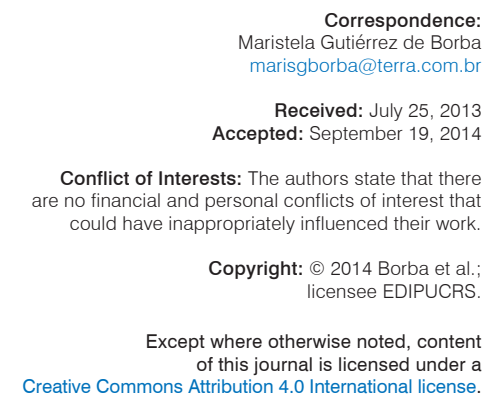




\section{Introduction}

Permanent tooth avulsion is one of the most serious dental trauma, in which the tooth is totally dislocated outside the alveolus and can cause serious damage to the periodontal structure [1]. Immediate replantation must be performed to allow the periodontal ligament repair and the maintenance of the radicular integrity with the cement coverage [2,3], although small areas of radicular resorption and anchylosis may appear in this situation [4]. However, due to other present injuries, the replantation cannot be always performed immediately. In these situations or when the tooth is not stored in an adequate storage medium, the chance of damage to the radicular surface with possibility of radicular resorption is high, which is the main cause of the replanted tooth loss [5]. There is meaningful relationship between the frequency of radicular resorption and the extraalveolar time and storage medium [6]. If the tooth is kept dry, the number of viable cells present in the radicular surface decreases as time raises and after two hours is impossible to find viable cells [7]. So, the dry storage is considered extremely deleterious to the normal periodont [6]. Thus, the tooth must be stored in a medium that keep the adherence ability and periodontal ligament cells viability and available at the avulsion place when the immediate replantation cannot be performed $[4,8,9]$. Osmolarity and $\mathrm{pH}$ are important factors to the cell viability conservation, and its growth happens mainly at osmolarity of $230-400 \mathrm{mOsm} / \mathrm{kg}$ and $\mathrm{pH}$ of 6.6-7.8 $[10,11]$. The storage media vary according to the electrolytes' concentration and the osmolarity, and the protection of the periodontal ligament is more related to osmolarity of solutions than to chemical composition $[6,12]$. At a hypotonic medium the cells expand and disrupt, whereas at hypertonic medium the cells shrink due to the osmotic movement of liquid outflow and both are critic to cell viability $[6,13]$.

Many solution have been studied as possible tooth storage media. The proposition of this paper is to present a review of literature about the most used storage media for tooth avulsion.

\section{Literature Review}

\section{Water}

Water is easily found in most places where tooth avulsion usually happens. Though, water cause fast necrosis of the periodontal ligament and radicular resorption due to the hypotonic properties, acid $\mathrm{pH}$, chlorine presence and high incidence of microorganisms contamination $[6,8,11,14-16]$. This and the fact that causes more substitutive resorption than other media, as saliva and saline [6], its clinical application is unacceptable. Many studies include water as negative control.

\section{Saliva}

Since the $70 \mathrm{~s}$ saliva was recommended as storage medium for avulsed tooth, that should be placed at the oral cavity or in a recipient that contains saliva expelled by the patient [17]. Even with better results than water [18], it presents low performance due to its hypotonic properties [8]. Furthermore, bacteria and its byproducts might be present and potentiate cell damage started by hypotonicity, enhancing inflammatory response [18].

\section{Rehydration solution}

Coconut water is a natural drink, without contamination, produced and hermetically stored inside the coconut. Its electrolytic composition is more similar to the intracellular than the extracellular fluid. The predominant cations are potassium, calcium and magnesium. Sodium, chlorine and phosphate are found at lower concentrations. The osmolarity is high due to the present carbohydrates, mostly glucose and fructose [19]. This isotonic drink is available in its natural form, extracted directly from de coconut, at long-life package or plastic bottles, mainly at tropical countries, and has been disseminated all over the world, which instigated researches about the use of this solution as a storage medium for avulsed teeth [20]. A study analyzed the viability of periodontal ligament in coconut water, HBSS and milk at 45 minutes, in which coconut water had statistically significant superior results, probably due to the nutrients present in this medium, like proteins, amino acids and minerals that help the cellular nutrition and keep its viability [20]. However, another research that used a more precise evaluation method, with analyzing periods of 1,2 and 4 hours, observed a decreasing capacity of maintenance of periodontal ligament cell viability using the following storage media: milk, saline, coconut water with sodium bicarbonate, coconut water and mineral water [21]. This must be due to the fact that coconut water has an acid $\mathrm{pH}$ [7], deleterious to cell metabolism. When sodium bicarbonate is addicted to neutralize the $\mathrm{pH}$, the osmolarity increases, what might have contributed to the maintenance of cell viability. Even so coconut was similar to saline and, for practical application, its use is not applicable due to the difficulty to neutralize the $\mathrm{pH}[21]$.

The oral rehydration solution Gatorade ${ }^{\circledR}$ presents physiologic osmolarity, carbohydrate, which could supply energy to the periodontal ligament cells, but has acid $\mathrm{pH}$, which could be responsible for the low capacity to maintain cell viability [8]. Thus, the oral rehydration solution Gatorade $^{\circledR}$ is considered inadequate as storage medium for an avulsed tooth [13].

Milk

Milk is considered a suitable storage medium for avulsed teeth, as presents physiologic compatible $\mathrm{pH}$ and osmolarity, essential nutrients, growth factors [9,22], besides easily accessible [13].

The pasteurized milk has low bacterial level, which represents an advantage over bovine milk in natura [14]. The long-shelf life milk has almost the same composition, $\mathrm{pH}$ and osmolarity of the pasteurized milk, its storage is easier and its shelf life is superior. Both pasteurized and 
long-shelf life milk were superior to Save-A-Tooth (HBSS based commercial product) for maintaining cell viability, and are considered effective storage media [15].

The variation of milk fat content does not modify its properties, neither its constituents, keeping similar $\mathrm{pH}$, osmolarity, carbohydrates and proteins contents. Though, fat content seems to have some effect on cell viability, which suggests low fat milk might be more appropriate to maintenance of periodontal cell viability [8].

Milk reconstituted formulas, which do not require refrigeration, have higher shelf life and are easily transported, were compared to pasteurized milk. After 2 hours, the infantile milk formulas tested were superior to pasteurized milk, but after 8 hours, the pasteurized milk had superior performance than other substitutes. Carbohydrates, proteins and growth factors in infantile milk justify this better result until a period of 4 hours. Although, after this time, the dehydration process might destroy other growth factors present in the milk, resulting in lower performance [23].

Soymilk has approximately the same proportion of proteins from bovine milk, is a good source of vitamins and minerals, has low level of saturated fats, does not have cholesterol and presents physiologic $\mathrm{pH}$ and osmolarity, also considered an adequate storage medium [14].

Although milk has high acceptance as storage medium, still there is not a consensus in the literature related to the time of storage it is capable of maintaining the periodontal ligament cells viability [24]. Some studies considered milk as an appropriate storage medium since the extraoral time does not exceed 2 [25], 3 [26] and even 6 hours [27]. A possible explanation is that the researches use different methods and different milk types, fibroblast origin and evaluation methods.

Considering that after 6 hours the milk lose effectiveness, and that most accidents are not so severe, the interval of 6 hours is reasonable for searching a dentist to replant the tooth [27]. Other positive aspect to be considered is the low cost, which make this an accessible storage medium for the population in general.

The effectiveness of milk in comparison to other storage medium is also controversial. A study [13] shows that it is so good or even better than Save-A-Tooth (SAT) for until 12 hours due to its physiologic osmolarity and the presence of growth factors. It is important to emphasize that SAT is a HBSS based commercial product, and maybe the result could have been different if HBSS had been employed.

The need to daily renew the milk promotes a negative effect on cell viability. It is possible that milk reposition remove the growth factors and proteins and hinder the cell metabolism. Furthermore, the aspiration might have a negative effect on the confluent cell monolayer. Maybe the renovation in bigger intervals may compensate the $\mathrm{pH}$ decrease and cause lower damage to the organization of confluent cell monolayer [28].

There is not an agreement about the effect of temperature on the storage media effectiveness. Some authors [29] report low temperature $\left(4^{\circ} \mathrm{C}\right)$ limit bacterial growth, while others [24] consider that skimmed milk kept at ambient temperature $\left(20^{\circ} \mathrm{C}\right)$ until 48 hours is an adequate storage medium. However, other researchers [30] consider that since the periodontal ligament is stored in a favorable medium, the temperature has only a secondary function.

\section{Cell culture media}

HBSS (Hank's balanced salt solution) is a solution used as storage medium that presents physiologic $\mathrm{pH}$ and osmolarity. Due to its ability to maintain periodontal cells viability and proliferation for 48 hours, it is recommended by the International Association of Dental Traumatology and by the American Academy of Endodontists as storage medium for avulsed teeth [11, 31, 32]. HBSS is commercially found as Save-A-Tooth and can be acquired by internet, although it is not easily found at drugstores all over the world.

Viaspan is a storage medium used for organs transplants, sold at the United States. It has similar results to HBSS and superior to milk used as storage media [27].

Euro-Collins solution, developed for hypothermic preservation of organs for transplant, presents physiologic $\mathrm{pH}$ and osmolarity and as storage medium showed better results than milk, and similar to the immediate replantation [1].

Although their positive biological effects, the culture media are considered impracticable, as they are rarely accessible at the accident place and even in the international market. Thus, the interest in these media is merely academic.

\section{Growth factors}

Studies have demonstrated that the biological mediators called growth factors are capable to promote cell proliferation. The PDGF is a growth factor derived from platelets that has high mitogenic effect on periodontal ligament cells, also acting as chemotactic agent and stimulate protein synthesis of mesenchymal cells and the production of other growth factors as TGF- $\beta$ [33-35]. After the exposition to PDGF, the fibroblasts induce incorporation of thymidine in 12-16 hours and this conducts to the cell duplication in 30-36 hours [34]. This suggest that PDGF plays an important role in the maintenance of periodontal ligament cell viability. The addition of PDGF to Save-A-Tooth enhances the ability of this storage medium to maintain cell viability, which indicates that PDGF has a stimulating effect on cells and is capable to increase the number of viable cells [13].

\section{Green tea}

Green tea is the second most consumed drink in the world, losing only to water [36]. Due to this fact, the effectiveness of the green tea extract (GTE) to maintain periodontal ligament cell viability was assessed and showed similar results to HBSS and better than milk [37]. The presence of catechin in GTE, an antioxidant agent highly effective in the maintenance of cell viability, antibacterial and anti-inflammatory properties, might explain the better result than HBSS, but this has to be confirmed by future studies, as its efficacy to prevent root resorption [37]. 
The commercial green tea presents inferior results than GTE, HBSS and milk, due to its low osmolarity, which might lead to periodontal ligament cells necrosis, but was superior than water and could be considered an adequate storage medium until 1 hour after the avulsion [37].

The EGCG is the main polyphenol of the green tea and, when compared to HBSS and milk at 2 hours, presents better results in the maintenance of cell viability [38], and can be considered a therapeutic option [39]. Still, it could promote a favorable replantation with low infection levels and lower incidence of resorption and anchylosis [37], as EGCG can inhibit osteoclasts formation [40], cytokines production [41] and the inflammatory pathways [42].

\section{Propolis}

Propolis is a resinous substance produced by bees to cover and protect the hive [4]. It is composed by vitamins, mineral salts, flavonoids, fatty and aromatic acids, esters, wax, pollen, volatile substances and some yet unknown [43]. Propolis presents antibacterial, antifungal, antiviral [44] and antioxidant [45] actions and is capable to accelerate the repair process in several tissues [46].

The viability of periodontal ligament cells kept for 45 minutes in different concentrations of propolis (50 and $100 \%$ ) was assessed and showed better results than HBSS, saline and milk. However, the evaluation method was trypan blue calculation, that assess only the cell viability and not the physiologic condition, neither the metabolic capability, which are the viable cells health status and knowingly critical for prevention of root resorption after the replantation [47].

Other study [4] found similar results between immediate replantation, propolis solution and milk after 6 hours, but at 1 hour the result was not stimulant. A possible explanation is that the better incorporation of active principles of propolis responsible for the antibacterial antimicrobial, antiinflammatory, antioxidant actions and healing occurs when the tooth is kept in this medium for a higher time [11, 47].

The addition of HBSS to propolis to combine its well established properties as storage medium promoted decrease in apoptosis level, increased cell viability and better physiologic condition [48].

Although the biological properties of propolis have been demonstrated in vitro as described above, a study using dogs demonstrated that though the propolis extract have been effective in the maintenance of periodontal cell viability, this storage medium could not prevent substitutive root resorption, similar to saliva and the dry tooth, while milk presented better results, similar to HBSS [11].

\section{Others}

Saline solution is an isotonic storage medium that sometimes is available when the dental trauma occurs, and presents similar results to milk at 2 hours period [25].

The egg albumin presents high concentrations of proteins, vitamins, water and is not contaminated by microorganisms [49]. The periodontal repair of avulsed teeth was evaluated in egg albumin and milk at 3, 6 and 10 hours.
This study found better results in teeth immersed in albumin for 6 hours and considered this as an adequate storage media for until 10 hours [49].

Due to the benefits of probiotics in the gastrointestinal tract in enhancing resistance to infections, the periodontal ligament cells viability was assessed kept in HBSS, saline and probiotic solution (L. reuteri) for 45 minutes. The results showed that there was not statistically significant difference between the storage media. The authors consider the probiotic solution an appropriate medium, although it is still needs new researches [17].

\section{Concluding Remarks}

The avulsed tooth replantation success is dependent mainly of prevention and/or limitation of substitutive root resorption. Thus, the treatment must reestablish the periodontal ligament physiology as soon as possible. There are two key aspects in that situation: time that the tooth is kept outside the alveolus and the storage medium in which it is maintained. After avulsion, the reminiscent periodontal ligament on the radicular surface depends of vital metabolic supplies. The destruction starts when these metabolites are denied. To preserve the cell metabolism these supplies need to be reestablished. If the cells survive, they will catalyze the reproduction of new cells that could differentiate and reinstall the support tissues. To minimize the consequences after the replantation, the avulsed teeth must be stored in a solution that preserves the viability of the periodontal ligament cells.

The storage media must mimetize the oral environment most as possible. Thus, the reposition of physiologic metabolites, $\mathrm{pH}$ and osmolarity are properties that must be considered to choose a storage medium, beyond being easily found at the accident place. Although many studies had been performed, until now there is not a storage medium that fulfills the cited requisites. Besides, from the clinical evaluation, milk could be an adequate option when the immediate replantation is not possible.

\section{Acknowledgements}

This study was supported in part by grants from the National Council for Scientific and Technological Development (CNPq) - grant \#161947/2011-5 to MGB, \#306394\2011-1 to CE.

\section{References}

1. Sottovia AD, Sottovia Filho D, Poi WR, Panzarini SR, Luize DS Sonoda CK. Tooth Replantation After Use of Euro-Collins Solution or Bovine Milk as Storage Medium: A Histomorphometric Analysis in Dogs. J Oral Maxillofac Surg. 68:111-119, 2010.

2. Andreasen JO. Analysis of topography of surface - and inflammatory root resorption after replantation of mature permanent incisors in monkeys. Swed Dent J. 1980;4:135-44.

3. Andreasen JO. Analysis of pathogenesis and topography of replacement root resorption (ankylosis) after replantation of mature permanent incisors in monkeys. Swed Dent J. 1980;4:231-40.

4. Mori G, Nunes DC, Castilho LR, Moraes IG, Poi WR. Propolis as storage media for avulsed teeth: microscopic and morphometric analysis in rats. Dental Traumatol. 2010; 26: 80-85

5. Panzarini, SR, Gulinelli JL, Poi WR, Sonoda CK, Pedrini D, Brandin DA. Treatment of root surface in delayed tooth replantation: a review of literature. Dent Traumatol. 2008; 24: 277-282. 
6. Andreasen JO. Effect of extra-alveolar period and storage media upon periodontal and pulpar healing after replantation of mature permanent incisors in monkeys. Int J Oral Surg. 1981;10:43-53.

7. Soder PC, Otteskog P, Andreasen JO, Modéer T. Effect of drying on viability of periodontal membrane. Scand J Dent Res. 1977;85: 164-8

8. Harkacz OM, Carnes DL, Walter WA. Determination of periodontal ligament cell viability in the oral rehydration fluid Gatorade and milks of varying fat content. J Endod. 1997;23:687-90

9. Chamorro MM, Regan JD, Opperman LA, Kramer PR. Effect of storage media on human periodontal ligament cell apoptosis. Dent Traumatol. 2008;24:11-6.

10. Khademi AA, Saei S, Mohajeri MR, Mirkheshti N, Ghassami F, Torabinia $\mathrm{N}$ et al. A new storage medium for an avulsed tooth. J Contemp Dent Pract. 2008;9:25-32.

11. Casaroto AR, Hidalgo MM, Sell AM, Franco SL, Cuman RKN Moreschi E et al. Study of the effectiveness of propolis extract as a storage medium for avulsed teeth. Dent Traumatol. 2010; 26 : 323-331;

12. Lindskog S, Blomlöf L. Influence of osmolality and composition of some storage media on human periodontal ligament cells. Acta Odontol Scand. 1982;40:435-41.

13. Olson BD, Mailhot JM, Anderson RW, Schuster GS, Weller RN Comparison of Various Transport Media on Human Periodontal Ligament Cell Viability. J Endod. 1997; 23: 676-679.

14. Moazami F, Mirhadi H, Geramizadeh B, Sahebi S. Comparison of soymilk, powdered milk, Hank's balanced salt solution and tap water on periodontal ligament cell survival. Dental Traumatol. 2012; 28 : 132-135.

15. Marino TG, West LA, Liewehr FR, Mailhot JM, Buxton TB, Runner $\mathrm{RR}$ et al. Determination of periodontal ligament cell viability in long shelf-life milk. J Endod. 2000;26:699-702

16. Sigalas E, Regan JD, Kramer PR, Witherspoon DE, Opperman LA Survival of human periodontal ligament cells in media proposed for transport of avulsed teeth. Dent Traumatol. 2004;20:21-8.

17. Çaglar E, Sandalli N, Kuscu OO, Durhan MA, Pisiriciler R, Calıskan EA et al. Viability of fibroblasts in a novel probiotic storage media. Dent Traumatol. 2010; 26: 383-387.

18. Blomlöf L Otteskog P Viability of human periodontal ligament cells after storage in milk or saliva. Scand J Dent Res. 1980;88:436-40.

19. Campbell-Falck D. Thomas T, Falck TM, Tutuo N, Clem K. The intravenous use of coconut water. Am J Emerg Med. 2000;18:188-91.

20. Gopikrishna V. Thomas T, Kandaswamy D. A quantitative analysis of coconut water: a new storage media for avulsed teeth. Oral Surg Oral Med Oral Pathol Oral Radiol Endod. 2008;105:e61-e65.

21. Moreira-Neto JJS, Gondim JO, Raddi MSG, Pansani CA. Viability of human fibroblasts in coconut water as a storage medium. Int Endod J. 2009:42: 827-830.

22. dos Santos CL, Sonoda CK, Poi WR, Panzarini SR, Sundefeld ML Negri MR. Delayed replantation of rat teeth after use of reconstituted powdered milk as a storage medium. Dent Traumatol. 2009;25: $51-7$.

23. Pearson RM, Liewehr FR, West LA, Patton WR, McPherson JC 3rd Runner RR. Human periodontal ligament cell viability in milk and milk substitutes. J Endod. 2003:29:184-6.

24. Souza BDM, Lückemeyer DD, Felippe WT, Simões CMO, Felippe MCS. Effect of temperature and storage media on human periodonta ligament fibroblast viability. Dent Traumatol. 2010; 26: 271-275.

25. Patil S, Dumsha TC, Sydiskis RJ Determining periodontal ligament [PDL] cell viability from exarticulated teeth stored in saline or milk using fluorescein diacetate. Int Endod J. 1994;27:1-5.

26. Blomlöf $L$. Milk and saliva as possible storage media for traumatically exarticulated teeth prior to replantation. Swed Dent J. 1981;(suppl 8) $1-26$.

27. Trope M, Friedman S. Periodontal healing of replanted dog teeth stored in Viaspan, milk and Hank's balanced salt solution. Endod Dent Traumatol. 1992;8:183-8
28. Souza DMB, Lückemeyer DD, Felippe W, Alves AMH, Simões CMO Felippe MCS. Effect of milk renewal on human periodontal ligament fibroblast viability in vitro. Dent Traumatol. 2012; 28: 214-216.

29. Ashkenazi M, Sarnat H, Keila S. In vitro viability, mitogenicity and clonogenic capacity of periodontal ligament cells after storage in six different media. Endod Dent Traumatol. 1999;15:149-156.

30. Schwartz O, Andreasen FM, Andreasen JO. Effects of temperature storage time and media on periodontal and pulpal healing after replantation of incisors in monkeys. Dent Traumatol. 2002;18 190-195.

31. Flores MT, Andersson L, Andreasen JO, Bakland LK, Malmgren B Barnett $F$, et al. Guidelines for the management of traumatic dental injuries. II. Avulsion of permanent teeth. Dent Traumatol. 2007;23: 130-6

32. Pohl $Y$, Tekin U, Boll M, Filippi A, Krischner $H$. Investigation on a cell culture medium for storage and transportation of avulsed teeth. Aus Endod J. 1999;25:70-5.

33. Matsuda N, Lin WL, Kumar NM, Cho MI, Genco RJ. Mitogenic chemotactic, and synthetic responses of rat periodontal ligament fibroblastic cells to polypeptide growth factor in vitro. J Periodontol. 1992;63:515-25

34. Ross R. Platelet derived growth factor. Ann Rev Med. 1987;38:71-9

35. Piche JE, Cames DL, Graves DT. InitiaJ characterization of cells derived from human periodontia. J Dent Res. 1989;68:761-7.

36. Yang CS, Maliakal P, Meng X. Inhibition of carcinogenesis by tea Annu Rev Pharmacol Toxicol. 2002:42:25-54.

37. Hwang JY et al. The use of green tea extract as a storage medium for the avulsed tooth. J Endod. 2011:37:962-967.

38. Chen H, Huang B. [-]-Epigallocatechin-3-gallate: a novel storage medium for avulsed teeth. Dent Traumatol. 2012; 28: 158-160.

39. Jung I et al. Effect of (-)-epigallocatechin-3-gallate on maintaining the periodontal ligament cell viability of avulsed teeth: a preliminary study. J Periodontal Implant Sci. 2011;41:10-16.

40. Yun JH, Pang EK, Kim CS, Yoo YJ, Cho KS, Chai JK et al. Inhibitory effects of green tea polyphenol (-)-epigallocatechin gallate on the expression of matrix metalloproteinase- 9 and on the formation of osteoclasts. J Periodontal Res. 2004:39:300-7.

41. Lee YL, Hong CY, Kok SH, Hou KL, Lin YT, Chen MH et al. An extract of green tea, epigallocatechin-3-gallate, reduces periapical lesions by inhibiting cysteine-rich 61 expression in osteoblasts. J Endod 2009:35:206-11.

42. Yang F, Oz HS, Barve S, de Villiers WJ, McClain CJ, Varilek GW. The green tea polyphenol [-]-epigallocatechin-3-gallate blocks nuclear factor-kappa B activation by inhibiting I kappa B kinase activity in the intestinal epithelial cell line IEC-6. Mol Pharmacol. 2001;60:528-33.

43. Burdock GA. Review of the biological properties and toxicity of bee propolis. Food Chem Toxicol. 1998;36:347-63.

44. Kujumgiev A, Tsvetkova I, Serkedjieva Y, Bankova V, Christov R, Popov S. Antibacterial, antifungal and antiviral activity of propolis of different geographic origin. J Ethnopharmacol. 1999; 64: 235-240.

45. Johnston JE, Sepe HA, Miano CL, Brannan RG, Alderton AL. Honey inhibits lipid oxidation in ready-to-eat ground beef patties. Meat Sci. 2005;70:627-631.

46. Magro-Filho O, Carvalho AC. Application of propolis to dental sockets and skin wounds. J Nihon Univ Sch Dent. 1990:32:4-13.

47. Martin MP, Pileggi R. A quantitative analysis of propolis: a promising new storage media following avulsion. Dent Traumatol. 2004;20:85-9

48. Gjertsen AW, Stothz KA, Neiva KG, Pileggi R, Effect of propolis on proliferation and apoptosis of periodontal ligament fibroblasts. Ora Surg Oral Med Oral Pathol Oral Radiol Endod. 2011;112:843-848

49. Khademi AA, Atbaee A, Razavi S, Shabanian M. Periodontal healing of replanted dog teeth stored in milk and egg albumen. Dental Traumatol 2008; 24:510-514. 